\title{
THE ST. THEODORE TYRON CULT IN THE NOVO HOPOVO MONASTERY
}

\begin{abstract}
The relics of the warrior saint Theodor Tyron were brought to the Novo Hopovo Monastery in the mid-16th century at the latest. The first records of the relics were found in a panegyric dating from 1555. Three manuscripts of the Tale of Theodore Tyron record a legend referring to the events occurring prior to the transfer of the saint's relics to Hopovo, as well as to their fate in the Fruška Gora monastery. The relics were kept in a casket and displayed in the bema, bestowing it a memorial character. Such manner of displaying the relics had already been established in the Žiča Monastery and was practised in numerous monasteries of Fruška Gora.
\end{abstract}

KEYWORDS: St Theodore Tyron; Novo Hopovo Monastery; cult of relics.

The cult of St Theodore Tyron, a martyr from the 4th century, ${ }^{2}$ started to develop in Srem in the mid-16th century, at the same time when the cult of St Stefan Stiljanović emerged (Грујић, 1939, pp. 410-411). The first records of his relics in the Novo Hopovo Monastery were found in a panegyric dating from $1555^{3}$ (Радичь, 1847, p. 36). Today we know about three manuscripts of the Tale of Theo-

$1 \quad$ b.gugolj@gmail.com

This paper was submitted on August $30^{\text {th }}, 2019$ and accepted for publication at the meeting of the Editorial Board held on September $16^{\text {th }}, 2019$.

2 St Theodore Tyron perished in the early 4 th century and already at the end of the century his cult developed and his temples were built from the mid-5th century. He was venerated not only in the East but in the West as well, and was the patron saint of Venice before the relics of Saint Mark were brought to the city (Стойкова, 2013, p. 4). 
dore Tyron ${ }^{4}$ which document events prior to the transfer of the saint's relics to the Hopovo Monastery and the fate of the relics in the monastery. Furthermore, the texts provide more information about the fate of the Serbian people in the 17th and early 18th centuries, so they are not only a hagiographic material but a specific historic source, as well. Ilarion Ruvarac $(1888$, p. 91) found the manuscript, Tale of Theodore Tyron, in the monasterial library and published the part referring to the events of the liberation of Buda from the Turks in 1686 and the period by the Great Migration in $1690 .^{5}$ Dimitrije Ruvarac also says that there were three manuscripts of the Tale $^{6}$ in Hopovo: a booklet written by the Hopovo abbot, old Cyril, in 1721 , a copy of the manuscript was published by Radić in the Hopovo monograph, as well as a copy of Cyril's document written in 1780 by a Hopovo hieromonk, Spiridon Jovanović. In his introduction, D. Ruvarac states that the Tale follows Cyril's original. ${ }^{7}$ In the monograph (1847, pp. 28-35), Irinej Radić, the Hopovo abbot, provides a copy according to Spiridon Jovanović but does not mention any other Tale manuscripts in Hopovo. In the text published by D. Ruvarac, omits the years and dates published in the manuscript by I. Ruvarac and Dimitrije Ruvarac also adds more sections than featured in the original. The Matica Srpska Library, Novi Sad, holds another version of the Tale of Theodore Tyron. Cyril's text ends with the year 1721, while the one in Matica Srpska describes the events occurring up to the Belgrade Peace Treaty in 1739, and ending with the death of Patriarch Arsenio IV. ${ }^{8}$ According to the mentioned texts and copies of the Tale of Theodore Tyron, his relics were purchased with gold by an Ardeal boyar from Hungary-Wallachia, who took them to his palace in Sibiu and placed them in the "gornica" or "čardak". He subsequently started to get rich. Later on, his widow, a wife of a different faith and ethnicity, neglected the relics altogether. A "builder" in wooden works, Radovan Rakić, a Serb from Ienu, found them neglected when he was called in to Sibiu to repair the boyar's house. According to the legend, St Theodor appeared to Radovan in his dream, so the

\footnotetext{
Tale of Theodore Tyron (= in Serbian: Повесіи o Теоgору Тирону)

Повесй о Теоgору Тирону, [published by] И. Веселинов, in: Трагом српске прошлости, (1991, pp. 80-81), providing comments on all three texts. with comments, see: Повесие о Теоgору Тирону, [published by] И. Веселинов, in: Трагом српске прошлости, (1991, р. 79-97).
} 
builder, after completing the house, asked the widow to pay him with the casket with the relics of St Theodore Tyron (Радичь, 1847, pp. 30-31). ${ }^{9}$ Then Radovan took the relics to the Hodoš Monastery where they remained for the next twenty five years, miraculously healing many visiting belivers. When the Hungarian Roman Catholic monks tried to persuade the military authorities to take the relics by armed force, the Hodoš monks smuggled them out by night, moving them to the Fruška Gora monastery of Hopovo. In 1555, the relics were in Hopovo but there is no record that they were brought or "newly brought" in that particular year, so it may be assumed that the transfer from Hodoš to Hopovo may have occurred on some earlier date, between 1520 and 1530 (Грујић, 1939, рp. 367-368, 410411). ${ }^{10}$ In Spiridon's text from 1780 , originating from an oral lore, it is said that after the relics were moved to Hopovo:

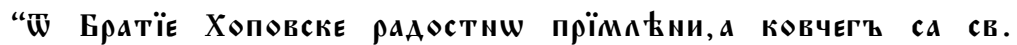

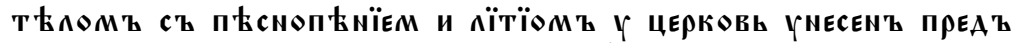

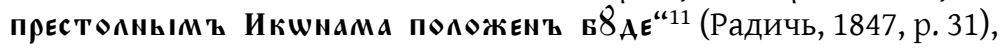

which determined a special purpose of this section of the temple.

The mentioned manuscripts, through the story about St Theodore Tyron's relics, provide some historical facts on the destructions and restorations of the Hopovo Monastery during the Austro-Turkish wars. The tragic events started in 1683 during the Turkish sieges of Belgrade and Vienna and the marching of the troops through Srem. Like all other monks and the local population, the Hopovo monks fled across the Sava River, carrying St Theodore Tyron's relics. First they went to Zaslon, present day Šabac, then to the Radovašnica Monastery where they stayed for a year. The Hopovo monks then went on to Irig, bringing the relics with them and placing them in a small church that once used to be a mosque. The relics remained there for four years until the church was restored. On the place of that mosque-church where the Tyron's relics were kept, a new church was built later on, dedicated to the saint. There are two texts recording that between the periods in Radovašnica and Irig, the Hopovo monks, with the relics, spent

9 Житије Св. Теодора Тирона, given by Д. Р[уварац], СС 20 (1904, p. 606).

10 Повесие о Теоgору Тирону, [published by] И. Веселинов, in: Трагом српске прошлости, (1991, pp. 80-81).

11 In English: "The Hopovo brotherhood received it rejoicing, and the chest with the body was brought to the church in a procession and singing, and was laid in front of altar icons". 
some time in Mitrovica, but that detail is not mentioned in Spiridon Jovanović's text. In the meantime, the Turks burnt down the Hopovo church and the monasterial buildings. After the repair works on the church, Tyron's relics were moved to Hopovo in 1689 (Радичь, 1847 , p. 31). ${ }^{12}$ According to I. Ruvarac's Tale (1888, p. 91), all this happened between 1686 and 1687. The second time the Hopovo monks fled with the relics was in 1690 . The reason was the fear of the Turkish revenge after they were driven out from Buda and the towns in Serbia. This time, with the refuge Serbian patriarch and the people, they went to Szentendre, where it is assumed the relics were brought to the St Nicholas Church which later on became known as the Opovo Church. Spiridon Jovanović narrates that after returning to Srem, hearing that it was not safe to go back, the monks stayed in Kovin for a while, where it is supposed someone of the Hopovo Church founder's descendants lived (Радичь, 1847, p. 31). Then they left for Baja where the saint's relics remained for three months. After that they returned to Hopovo (Радичь, 1847, p. 33). ${ }^{13}$ The third time the monks fled with the Theodore Tyron's relics was in 1716. It was the period of a second wave of Turkish attacks when the monasteries of Krušedol and Velika Remeta were burnt down. The Hopovo monks buried the relics on a secret place and fled. When the Turkish army was defeated and dispersed, the monks returned to the monastery, dug out the relics and took them to the cathedral in Novi Sad. Next year, in 1717, when the remaining Turkish troops were expelled, the monks, accompanied by the clergy and the people, moved the relics back to their monastery (Радичь, 1847, p. 34). ${ }^{14}$ Manuscript published by D. Ruvarac did not mention the relics being in Novi Sad. According to this text, they were taken from a secret grave in Hopovo, placed in a casket and taken to Kamenica and then to St George's Church in Šanac where they remained during the summer and then were brought back to Hopovo. ${ }^{15}$ The war operations and the migrations of 1737 under Ar-

12 Житије Св. Теодора Тирона, given bу Д. Р[уварац], CC 20 (1904), 607; Повесй o Teogopy Тирону, [published] И. Веселинов, in:Трагом српске прошлости, (1991, pp. 85, 94-95).

13 Житије Св. Теодора Тирона, given by Д. Р[уварац], СC 20 (1904, p. 608); Повесӣ o Теogopy Тирону, [published] И. Веселинов, in:Трагом српске прошлости, (1991, pp. 85, 95).

14 Житије Св. Теодора Тирона, given bу Д. Р[уварац], СC 20 (1904), 608; Повесӣ o Teogopy Тирону, [published] И. Веселинов, in: Трагом српске прошлости, (1991, pp. 85, 96).

15 Житије Св. Теодора Тирона, given by Д. Р[уварац], СС 20 (1904, p. 608). 
senio IV made the monks bury the relics once again and only after the peace treaty of 1739 they were returned to their place in the Hopovo church. ${ }^{16}$

Destruction of the monastery and the fate of the relics in the Second World War was recorded by monk Nikandar in the last pages of an Octoich:

„1943. год. 9/12 априла у 12 часова ноћи на велики четвртак трећи пут дошли партизани, опљачкали и спалили манастир Хопово. Све сестре су се преселиле у Ириг и сместиле по приватним кућама, дали су нам Успенску цркву где смо почели са богослужењем. 30. априла ове године Немци, мимо наше жеље превезли су нас у Београд, где и подносимо заједничке невоље рата. Чудесно сачувани Божијом милошћу сваки дан служећи сво правило и Свету Литургију. Чује се да је Хопово сасвим разрушено. 17/30. новембар 1943. год. Духовник манстира Хопово Јеромонах Никандар“17 (Николић, 2006, р. 9).

Through Mita, the monastery servant, the nuns informed the Irig priest Gojko Mihajlović about the whereabouts of the relics. He then bought a coffin, placed the relics in an oxcart and moved them to the church of St Theodore Tyron in Irig. Through the endeavours of monk Jovan, a carpenter Soter, of Armenian origin, made a new reliquary casket of walnut wood. In 1984, on the Feast of the Intersession of the Theotokos, the relics were formally returned to the Novo Hopovo Monastery (Николић, 2006, p. 10).

The Hopovo monks expressed their particular reverence for St Theodore Tyron's cult, whose relics had been kept there since the 1530s. When visiting the Fruška Gora monasteries in 1753, a committee recorded that there was an old casket, lost today, made of walnut wood with intarsia, where originally St Theodore Tyron's relics used to be kept (Хан, 1965, p. 148). ${ }^{18}$ The saint's body-his

16 Повесй о Теоgору Тирону, [published] И. Веселинов, in: Трагом српске прошлости, (1991, pp. 85-87, 97).

17 In English: "In 1943, on 9/12 April at 12 midnight on Maundy Thursday, the partisans came for the third time, looting and setting fire to the Monastery of Hopovo. All the nuns moved to Irig, staying in private houses, and we were given the Ascension Church, where we held the service. On 30 April this year, the Germans, contrary to our wishes, took us to Belgrade where we are all enduring the misfortunes of the war. Miraculously saved by the mercy of God, we regularly daily perform the Divine Liturgy. We have heard that Hopovo is completely demolished. On 17/30 November 1943. The Hopovo monk Nikandar".

18 Опис српских фрушкогорских манастира 1753.год, given by Д. Р[уварац], СC 18 (1903, Р. 560); Ойис срйских фрушкоїорских манасийра 1753.їog, given by Д. Р[уварац], (1903, р. 248). 
head, torso, arms, and legs at knees, all wrapped in the most precious fabrics-was lying in a simple casket placed on an exquisite Baroque throne. Thanks to a Hopovo archimandrite, Hadji-Zachary Milivojević and his efforts and endeavours in 1747, the monastery obtained "кивот нов от древа ораова израдњејше пилторским послом устројен"19, paid by Mihajlo Čokić of Bečej, that cost 513 florins and 13 cents. The casket contained "мноіойллебное йтло, иъплокуйно, св. великомученика Теоgора Тирона” (Остојић, 1907, p. 63) ${ }^{20}$ When a Hopovo delegation went to Russia in April of 1666, they asked for a contribution for a "shroud for the St Theodor Tyron's tomb, $195 \mathrm{~cm}$ long and $130 \mathrm{~cm}$ wide". They obtained a velvet shroud with gold crosses. ${ }^{21}$ In 1759, an "obstvohtmaister" Rista Joanović of Cerna, Slavonia, donated an embroidered red velvet shroud for the reliquary. ${ }^{22}$ We know about the look of the casket and the impressive Baroque throne, which was destroyed when the monastery was demolished in 1944 , from the archival material ${ }^{23}$ and photographs from the late 19th century (Figure 1) and the 1940s (Figure 2). ${ }^{24}$ The origin and the meaning of the throne shape where the casket with St Theodor Tyron's relics was placed were researched by M. Timotijević (2009a, pp. 123-138).

It is a well-known fact that warrior-martyrs' images and relics were used for protection and success in warfare. So it is no wonder that the St Theodor Tyron's relics found their place in Novo Hopovo

19 In English: "a new reliquary wood-carved of walnut wood". Опис српских фрушкогорских манастира 1753. год, given by Д. Р[уварац], СС 17 (1903, р. 533); Ойис срйских фрушкоїорских манасйира 1753. ìog, given by Д. Р[уварац], (1903, p. 244).

20 In English: "the relics, the entire healing body of St. Theodore Tyron". It was for the archimandrite, Haji-Zachary's endeavours that in 1751 a new church was built dedicated to St Pantaleon, instead of an old small wooden one in Staro Hopovo, dedicated to St Nicholas.

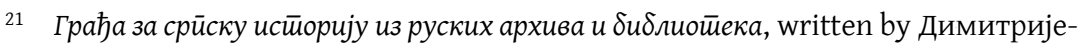
вић Ст. М. [sic! - edited], (1922, IV-V1, p. 204).

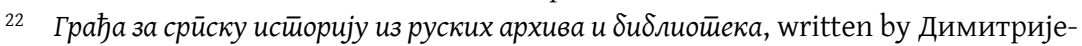
вић Ст. М. [sic! - edited], (1922, IV-V1, p. 180).

23 Опис српских фрушкогорских манастира 1753.год, given by Д. Р[уварац], СC 17 (1903, р. 533); Ойис срӣских фрушкоїорских манасйира 1753.īog, given by Д. Р[уварац], (1903, р. 244).

24 SASA Archives, 14484; 70533/11, boxes XXXV; Heritage Photo Archives of the Ministry of Culture of Croatia, Zagreb, inv. No. 6692, negative: VII - 155; Photo Archives of the Provincial Institute for the Protection of Cultural Monuments, Novi Sad, inv. No. 011, 013, scanned from glass plates kept at the "Fruska Gora" Mountaineering Society, taken by M. Popov, published in: Манојловић (1937, p. 51). 
in the tumults of the 16th century war. Christian belief that their holly protectors' influence and help in fighting the enemy actually comes from the beliefs recorded in the psalms and other Old Testament texts (Марковић, 1995, pp. 572-574). As in the late Middle Ages the relics of St Paraskevi's and those of St Luke's were brought to Serbia in order to provide protection to the people and the state in times of war with Turks, it is no wonder that St Theodor Tyron's relics were also brought to Serbia for the same reason, although History of Theodore Tyron do not say anything explicit about that. The significance of the relics is reflected in the records and inscriptions which testify that they were kept in St Nicholas's Church of the Hopovo Monastery. ${ }^{25}$ At the time Dositej Obradović stayed in Hopovo, the monastery celebrated St Theodor Tyrone as their patron saint (Остојић, 1907. pp. 71, 267, 294), and in the complex cadastre plan dating from the second half of the 19th century, it was marked as the monastery of St Nicholas and Theodor (Матић, 2007).

According to historical and visual art sources, as well as the most recent researches, the church bema used to have a memorial, for reliquary purposes. It may have been that the same memorial purpose was in place in the earlier temple whose foundations are beneath the church built in 1576. For quite a while it was a common knowledge that the relics of St Theodore Tyrone had been moved to Hopovo between 1520 and 1530 (Грујић, 1939, pp. 410-411). On the last page of a panegyric manuscript, which used to be kept in Hopovo, it was recorded:

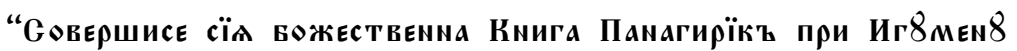

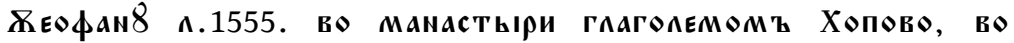

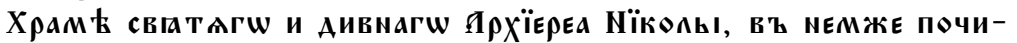

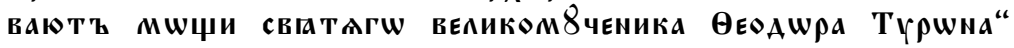
(Радичь, 1847, pp. 36). ${ }^{26}$
}

From the Visitation Committee report from 1753, as well as at the photographs dating from the second half of the 19th century, it can be seen that the throne with the St Theodore Tyron's reliquary

25 CC3H I, 584, 634, 956, 1502, 1593, 1707, 2044, 2057 (1902, pp. 185, 198, 269-270, 374375, 392, 414, 472, 475); CC3H II, 2196 (1903, p 22); CC3H IV, 6794, 7255 (1923, pp. 147, 224); ССЗН V, 7506, 7798 (1925, рр. 36, 80); Сйари срйски зайиси и найӣиси из Војводине I, 30, 1638 (1994, p. 9).

26 CC3H I, 584, (1902, p. 185), abbot Stefan is named here. In English: "It is finished this beautiful book, the Panegyric of Abbot Theofanis in 1555. in the monastery named Hopovo, in the temple of the holy and divine bishop Nikola, where the relics of a holy martyr Theodor Tyron lay". 
casket was in the bema area. The structure was actually placed in front of the south-east column (Тимотијевић, 1999, p. 134). ${ }^{27}$ And it stayed there until was destroyed in a mine explosion in 1943. In Novo Hopovo, as in other Fruška Gora monasteries, the reliquaries generally used to be displayed in front of the iconostasis, usually in front of the altar screen icons of Jesus and Mary. Such a way of displaying the reliquaries found in Vrdnik, Bešenovo, Privina Glava, Krušedol, Velika Remeta, and Rakovac (Кулић, 2003, pp. 172-179; Тимотијевић, 2009a, p. 23). The casket containing Prince Lazar's relics in Vrdnik used to stand in the church to the right in front of the iconostasis. Two chests with the relics of unknown saints used to be displayed before the temporary altar screen to the left and right. The chest with St Maxim and St Angeline Branković's relics and the hand of Stefan Branković was to the right in the bema area, in front of the two east columns. In Velika Remeta, the reliquary was to the left of the iconostasis, while in Rakovac, the structure with the chest was to the right before the iconostasis (Кулић, 2003, pp. 172-179). Such a way of displaying the relics was an expression of respecting the old practice kept in the Orthodox Church heritage. In the monastery churches of the Karlovci Metropolitanate, consistent with the tradition kept in the Patriarchate of Peć, no chapels or any special praying area were dedicated to the reliquaries in the church, but they were placed in front of the iconostasis. In order to be displayed properly, elaborate structures used to be built, turning the bema section into a luxurious stage scenery (Тимотијевић, 1999a, p. 137). The design of the Baroque throne for displaying the holy relics was finally defined only after the throne for St Theodore Tyron's relics had been placed in Novo Hopovo in 1747 and after making the thrones for the holy relics of the Srem Branković despots in the Krušedol Monastery in 1759 (Кулић, 2003, p. 172). The existing sources show that, already in the late 12th and early 13th centuries, the Serbian community was well aware of the meaning and function of the relics, although a crucial period in the development of cult of relics occurred in the Žiča Monastery. Imposing furniture made of stone in front of the altar screen was most probably used for displaying the relics. Those were the structures in a shape of deep proskynetarion with a canopy above (Поповић, 2006a, pp. 209-230; Поповић, 2006b, p. 257). The chest with the St Luke's relics had its honourable place "to the right from the roy-

27 www.kultura.hr/hr/zbirke/fototeka-kulturne-baštine/fruskogorski-manstiri, 21.11.2011, inv. No. 6690, negative VII-154, inv. No. 6692, negative VII-155. 
al doors" when it was translated to the Smederevo Metropolitanate and the rulers' tomb temple in 1453 (Поповић, 2006c, p. 307).

The Baroque throne for the casket with the relics of St Theodor Tyron's was placed in 1747 in the bema area that at that time was rather modest. The structure was in front of the south-east column supporting the dome. At that time, the old iconostasis was still there and, along the bema south wall, there was a bishop's throne. In the choir area there were the old seats. Only choir lecterns were new (Тимотијевић, 1999, p, 134). ${ }^{28}$ The new choir lecterns were introduced in the Karlovci Metropolitanate churches in the mid-18th century (Тимотијевић, 1994, pp. 50-51). A new iconostasis made in 1769 (Тодић, 2010, p. 346), ${ }^{29}$ and then a Virgin's throne placed in front of the north-east column gave the Hopovo bema area in the late 18th century Baroque look. In front of the Virgin's throne, like in Jazak, there was a chest with some traces and other relics that were in the possession of the monastery (Тимотијевић, 1999, p. 134). At that time, the church got a new flooring. There was a step between the naos and the narthex. Also, the altar apse floor was elevated with a step (Балаћ, 1958, р. 253; Тимотијевић, 1994, p. 54). ${ }^{30}$ Highlighting the bema area with levelling the floor was also done in other monasterial churches of the Karlovci Metropolitanate: in Krušedol (Тимотијевић, 2009b, pp. 34-35) and Šišatovac (Петровић, 1990, стр. 13). According to the Baroque concepts, the Hopovo bema area was designed as teatrum sacrum. Iconostasis, once considered a partitioning line between the altar and the Heaven, became a central scenery for the extended liturgical space and an allegorical image of the Heavenly Jerusalem front. The bema and the thrones with the relics symbolically became an antechamber of Heaven or the Heavenly Jerusalem (Тимотијевић, 2009b, pp. 3235 ). The front area of the scenery platform spread to the choirs on both sides, whose furniture consisted of old seats and new lecterns (Тимотијевић, 1994, pp. 49-54). ${ }^{31}$

28 Опис српских фрушкогорских манастира 1753.год, given by Д. Р[уварац], СC 18 (1903, р. 559); Ойис срӣских фрушкоіорских манастиира 1753. ìog, given by Д. Р[уварац], Сремски Карловци 1903, 243-244, 246.

29 Внуйр назнаменана Василием Неgељьковићем иіуменом Хойовским, СС 11, (1903), 302.

30 Тодић (2010, p. 347), provides information from Књиіе йриложника манасииира Хойова (ПБ, No. 363, sheet. 40,65) that in 1770 . Jovan Simić of Šarengrad donated three hundred white stone slabs for the "church floor".

31 Оӣис срӣских фрушкоїорских манасйира 1753.īog, given by Д. Р[уварац], (1903, p. 246). 
The sacred temple area at the time of its construction had not been structured in an imposing way. The grand ceremonial scenic character was being introduced gradually in the 18th century when the church was arranged according to the divine service reforms introduced by the Karlovci metropolitans. At the time of a general visitation in 1753 , the old church furniture was still in place. The old iconostasis with about 40 icons was replaced with a new one in 1769 , made according to a design by a woodcarver Thomas Firtler, while the icons were painted and completed by Theodor Kracun by 1776 Firtler also made a new bishop's throne and a small chest, and in October 1770, twenty two seats in the choir were added. ${ }^{32}$ The background of the scenery visible to the worshipers featured an iconostasis with tetrapods with icons, choir lecterns and seats, a bishop's throne and thrones with relics. One of the Baroque concept of a temple and an interior sacred space was to display the relics in an imposing manner, bringing them to the foreground.

The bema area memorial structure was lost in the Second World War. The chest and the throne for Theodore Tyrone's relics were destroyed in 1943, while the relics themselves were taken from the monastery. The Virgin's throne was destroyed as well, along with the choir lecterns. In the conservation and restoration works conducted in the second half of the 20th century, the floors were made of brick that belonged to the original pavement, whereas the floor levelling was not renewed. When St Theodor Tyron's relics were returned to the monastery in 1984, the bishop decided the reliquary to be placed in the north choir (Figure 3). The newly established memorial space was not arranged in accordance with the mediaeval tradition of displaying the relics, and it also departs from the Baroque concept introduced to the church in the second half of the 18 th century.

ABBREVIATIONS
САНУ = Српска академија наука и уметности

ГзПСКВ = Грађа за проучавање споменика културе Војводине

ЗлУМС = 3борник за ликовне уметности Матице српске

$\mathrm{CC} 3 \mathrm{H}=$ Стари српски записии натписи

СС $=$ Српски Сион

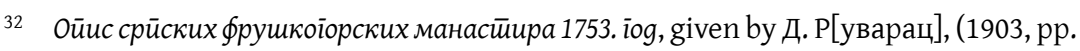
243-244); Тодић, (2010, p. 346), explains a misunderstanding about an earlier attribution stating that the "iconostasis" was made by woodcarvers Paul and Anton Resner, see: Остојић, (1907, p. 111, note 5). 


\section{SOURCES}

PUBLISHED SOURCES
Архив САНУ, 14484; 70533/11, кутија XXXV (=SASA Archives, 14484; 70533/ 11, boxes XXXV).

Фототека Покрајинског завода за заштиту споменика културе, Нови Сад, инвентарски број: 011, 013 (= Photo Archives of the Provincial Institute for the Protection of Cultural Monuments, Novi Sad, inv. No. 011, 013, scanned from glass plates kept at the „Fruska Gora“ Mountaineering Society).

Фототека споменичке ठаштине Министарства културе Хрватске, Загреб, www.kultura.hr/hr/zbirke/fototeka-kulturne-baštine/fruskogorski-manstiri, приступљено 21.11.2011, инвентарски број: 6692, негатив VII-155 (=Heritage Photo Archives of the Ministry of Culture of Croatia, Zagreb, inv. No. 6692, negative: VII - 155.

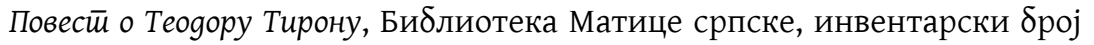
113456, сигнатура PP 190 (= History of Theodore Tiron, The Matica Srpska Library, inv. No.113456, signature PP 190).

(1903), Внутр назнаменана Василием Недељковићем игуменом Хоповским, СС 11, 302.

Грађа за срӣску исӣорију из руских архива и библиойека, написао Ст. М. Димитријевић [sic! - припремио], Сарајево 1922.

Житије Св. Теодора Тирона, приопштио Д. Р[уварац], СС 20 (1904), 605608.

Опис српских фрушкогорских манастира 1753.год, приопштио Д. Р[уварац], Сремски Карловци 1903. СС 16, (1903), 496-500; 17, (1903), 530-533; 18 , (1903), 559-564.

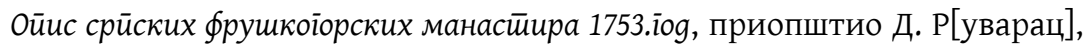
Сремски Карловци 1903.

Повест о Теодору Тирону, [објавила] И. Веселинов, у: Траїом срӣске йроилост̄u, Нови Сад 1991, 79-97.

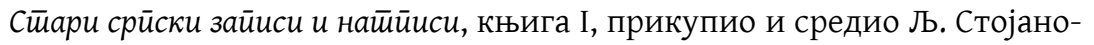
вић, Београд 1902.

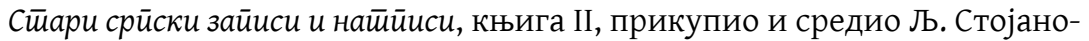
вић, Београд 1903.

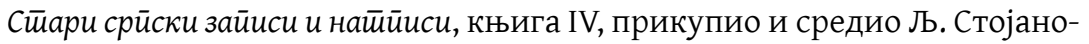
вић, Београд 1923.

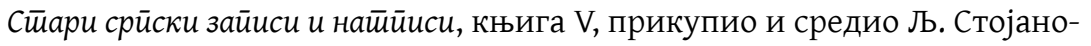
вић, Београд 1925.

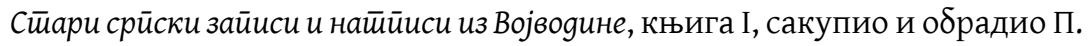
Момировић, Нови Сад 1994. 


\section{ILLUSTRATIONS}

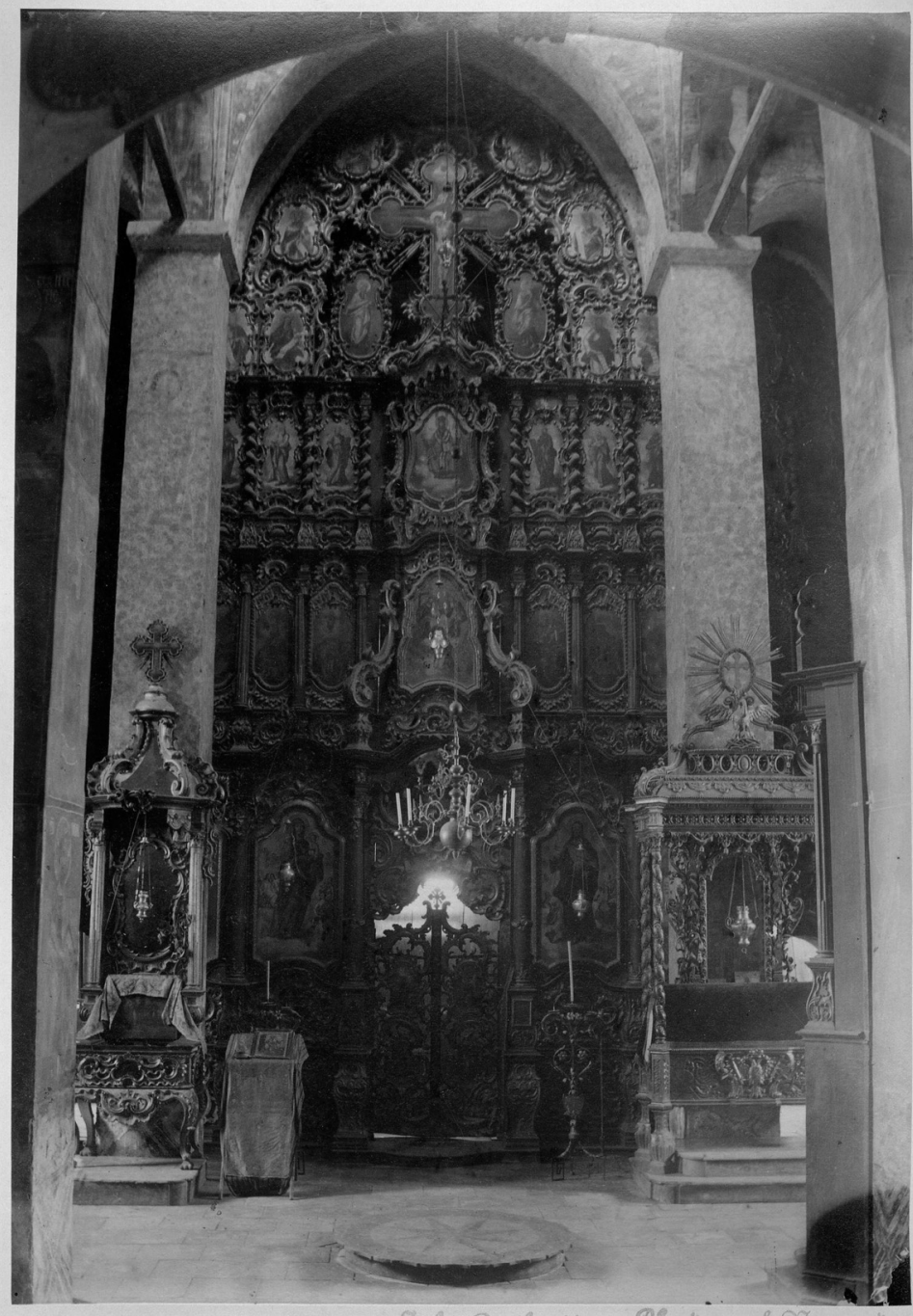

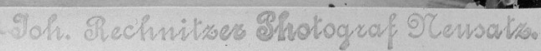

FIGURE 1: EAST SIDE OF THE NAVE IN FRONT OF THE ALTAR, SASA ARCHIVES, 14484; 70533/11, BOXES XXXV. 


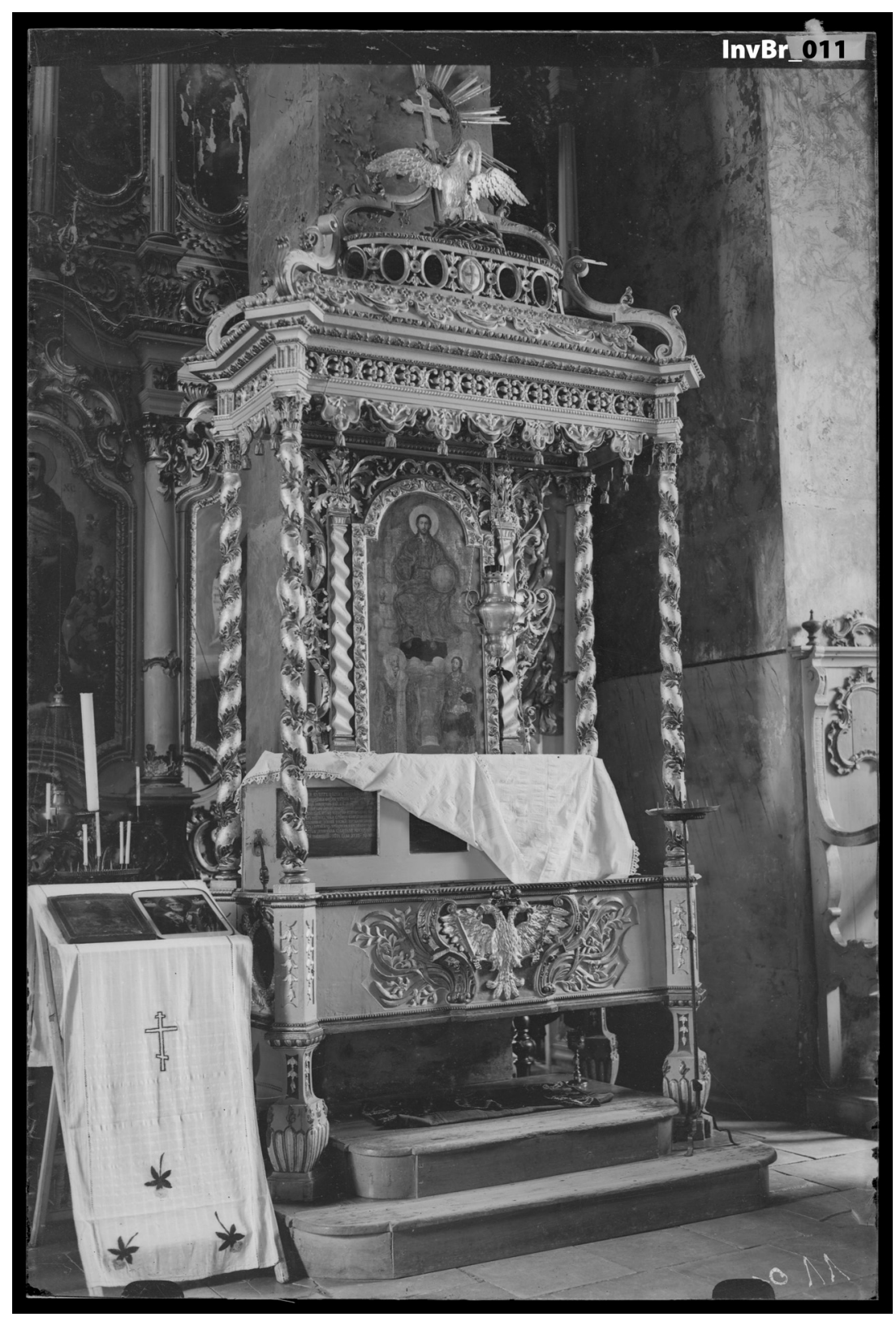

FigURE 2: THRONE WITH THE CASKET WITH RELICS OF THE ST. THEODOR TYRON, SOUTHEAST SIDE of the NAVE, Photo ARCHIVES OF THE PROVINCIAL InSTITUTE FoR THE PROTECTION of Cultural Monuments, Novi SAD, inV. No. 011, SCANNED FROM GLASS Plates KePT AT THE "FRUSKA GORA" MOUNTAINEERING SOCIETY. 


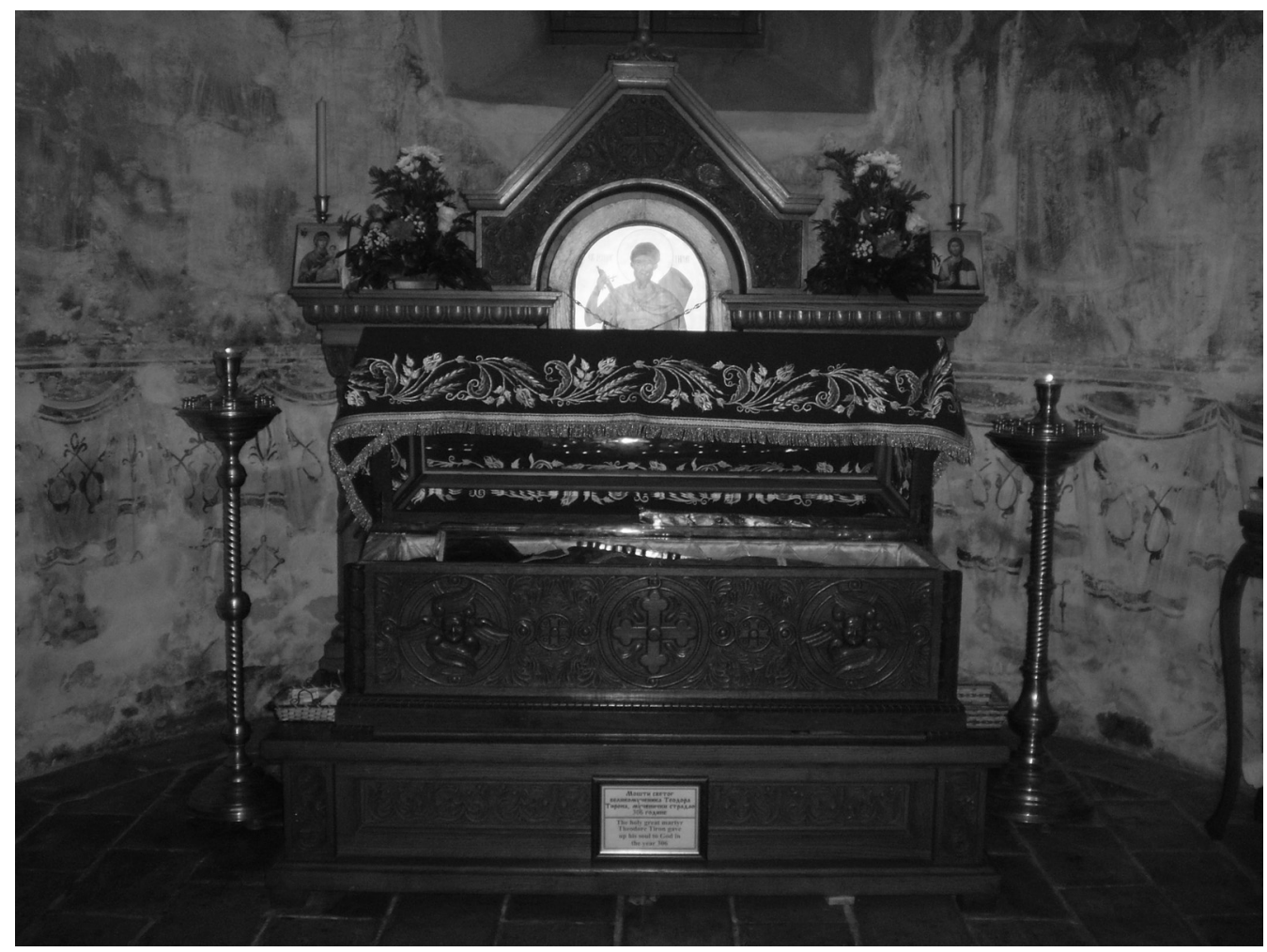

FigURE 3: THRONE WITH THE CASKET WITH RELICS OF THE ST. THEODOR TYRON, NORTH CHOIR OF THE CHURCH, (PHOTO BY B. GUGOLJ).

REFERENCES Балаћ, М. (1958). Радови у манастиру Новом Хопову 1958. године. ГзПскВ 2, 251-256.

Грујић, Р. (1939). Духовни живой, Војвоgина I: og најсӣаријих времена gо велике сеобе. Нови Сад: Историјско друштво, 410-411.

Кулић, Б. (2003). Тронови за свете мошти у Фрушкогорским манастирима средином XVIII века. ЗмСлУ 32-33, 171-182.

Манојловић, А. (1937). Срӣски манасӣuри у Фрушкој Гори. Сремски Карловци: Патријаршиска штампарија.

Марковић, М. (1995). О иконографији светих ратника у источно-хришћанској уметности и о представама ових светитеља у Дечанима. У:

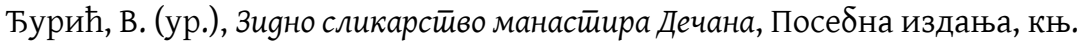
DCXXXII, Одељење историјских наука, књ. 22 (567-630). Београд: Српска академија наука и уметности.

Матић, В. (2007). Манасӣup С̄̄аро и Ново Хоӣово. Нови Сад: Платонеум. 
Николић, Н. (2006). Манасӣuр Ново Хоӣово. Ириг.

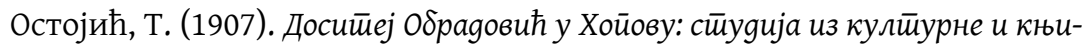
жевне ист̄орије. Нови Сад: Матица српска.

Петровић, М. (1990). Истраживање манастира Шишатовца, ГзПСКВ, XVI, $12-23$.

Поповић, Д. (2006а). Sacrae reliquiae Спасове цркве у Жичи. У: Поповић,

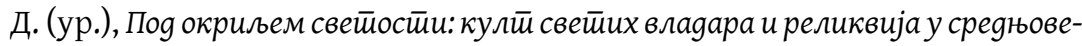
ковној Србији (207-232). Београд: Балканолошки институт САНУ.

Поповић, Д. (2006b). Реликвије и политика: српски приступ, у: Поg окри-

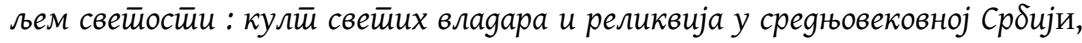
Београд: Балканолошки институт САНУ, 253-270.

Поповић, Д. (2006с), Мошти светог Луке - српска епизода. У: Поповић, Д.

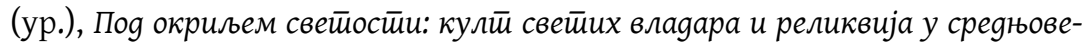
ковној Србији (295-317). Београд: Балканолошки институт САНУ.

Тимотијевић, М. (1994). Улога музике у уобличавању црквеног ентери-

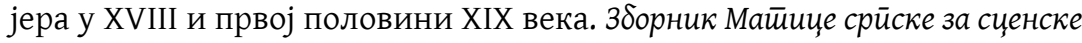
умейностии и музику, 15, 47-64.

Тимотијевић, М. (2009а). Трон за кивот са моштима светог Теодора Тирона у манастиру Ново Хопово - порекло облика и значење. ГЗПСКВ, XX, 123-138.

Тимотијевић, М. (2009b). Мошти светих деспота Бранковића и меморијска структура сакралног простора главног крушедолског храма. У: Тимотијевић, М. (ур.), Тронови иркве манасӣира Крушеgола (15-53). Нови Сад: Галерија Матице српске.

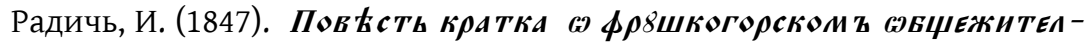
ном т манастьюр Хопов8, Вұ Б8Аин

Руварац, И. (1888). О ӣeћким ӣаӣријарсима оg Макарија gо Арсенија III (15571690). Задар: И. Водицка.

Стойкова, А. (2013). Св. Теодор Тирон и Св. Теодор Стратилат: още по въпроса за едноименните светци, Paleobulgarica, XXXVII (2), 3-22.

Тодић, Б. (2010). Необјављени податак о дрворезбару хоповских иконостаса. У: Тодић, Б. (ур.), Раgови о срйској умейносйи и умейнициима XVIII: йо архивским и gруіим йоgациима (343-349). Нови Сад: Галерија Матице српске.

Хан, В. (1965). Интарзирани предмети XVI и XVII столећа из цркава фрушкогорских манастира. ЗЛУМС, 1, 145-158. 
БРАНКА М. ГУГОљ

УНИВЕРЗИТЕТ У ПРИШТИНИ СА ПРИВРЕМЕНИМ СЕДИШТЕМ

у КОСОВСКОЈ МИТРОВИЦИ

ФАКУЛТЕТ УМЕТНОСТИ, ЗВЕЧАН - КОСОВСКА МИТРОВИЦА

РЕЗИМЕ

КУЛТ СВ. ТЕОДОРА ТИРОНА У МАНАСТИРУ НОВО ХОПОВО

Култ Св. Теодора Тирона, мученика из IV века, почео је да се развија у Срему половином XVI века, у исто време када и култ Св. Стефана Штиљановића. Први познати помен његових мошти у манастиру Ново Хопово је запис у панегирику из 1555. године. Данас су позната три рукописа Повесӣи о Теоgору Тирону у којима је изнето предање које се односи на догађаје који су претходили преносу светитељевих мошти у Ново Хопово, као и оне који се односе на њихову судбину у овом манастиру. Уз то, ови списи доносе и низ података који се односе на судбину српског народа y XVII и првим деценијама XVIII века, те тако не представљају само хагиографски спис већ су и својеврстан историјски извор. Према наведеним списима и преписима Повесӣu о Теogopy Тuрону његове мошти откупио је златом један ердељски бољар у Угаровлашкој и пренео у своју палату у Сибињу. Сасвим запуштене нашао их је „неимар“ у дрвеним делима Радован Ракић, Србин из Јенопоља, откупио их и пренео у манастир Ходош где су почивале двадесет пет година и чудотворном моћи лечиле многе који су им с вером прилазили. Када су мађарски римокатолички калуђери почели да наговарају војне власти да оружјем отму мошти, ходошки калуђери су их ноћу изнели и пренели у фрушкогорски манастир Хопово, где је, према легенди, из њих потекло миро. Пренос из Ходоша у Хопово збио се између 1520. и 1530. године. Према спису насталом по усменом предању мошти Св. Теодора Тирона постављене су испред иконостаса. Предолтарски простор цркве тако је добио реликвијарну меморијску намену, која је била наглашена нивелацијом пода. Светитељеве мошти чуване су у кивоту од ораховог дрвета украшеног интарзијама до 1747. када је израђен нови кивот који је постављен на репрезентативно изведен барокни трон. Такав образац излагања реликвија познат је и у другим фрушкогорским манастирима: Врднику, Бешенову, Привиној Глави, Крушедолу, Великој Ремети и Раковцу. Сачувани извори показују да су у српској средини већ крајем XII и почетком XIII века смисао и функција реликвија били добро познати. Кључна тачка у развоју култа реликвија до- 
годила се у Жичи, где је свечани камени намештај пред олтарском преградом вероватно служио за излагање реликвија. Познато је да су представе и реликвије мученика - ратника биле употребљаване за заштиту и успешно ратовање. Стога не треба да чуди да су се мошти Св. Теодора Тирона нашле у Хопову управо у време ратног вихора у XVI веку. Колики су значај имале мошти Теодора Тирона говоре бројни записи и натписи у којима се истиче да се оне налазе у цркви Св. Николе манастира Хопова. Меморијска структура предолтарског простора изгубљена је у току Другог светског рата, када су кивот и трон за мошти уништени, а мошти однете из манастира. Трудом и настојањем јеромонаха Јована дуборезац Сотер начинио је нови кивот од ораховог дрвета, а 1984. године мошти су свечано пренете из Ирига у цркву манастира Ново Хопово. Одлуком епископа постављене су у северној певници. Новоформирани меморијски простор није решен у складу са средњовековном традицијом излагања реликвија, а одступа и од барокне концепције која је уобличена у хоповском храму у другој половини XVIII века.

КљУчнЕ РЕчи: Свети Теодор Тирон; Манастир Ново Хопово; култ реликвија.

Овај чланак је објављен и дистрибуира се под лиценцом Creative Commons Ауторство-Некомерцијално Међународна 4.0 (CC BY-NC 4.0|

https://creativecommons.org/licenses/by-nc/4.0/).

This paper is published and distributed under the terms and conditions of the Creative Commons Attribution-NonCommercial International 4.0 licence (CC BY-NC 4.0 | https://creativecommons.org/licenses/by-nc/4.0/). 